\title{
Correction to: Adsorption, Kinetics and Equilibrium Studies on Removal of Catechol and Resorcinol from Aqueous Solution Using Low-Cost Activated Carbon Prepared from Sunflower (Helianthus annuus) Seed Hull Residues
}

\author{
Ephraim Vunain • Dégninou Houndedjihou • \\ Maurice Monjerezi • Adolph Anga Muleja • \\ BarthélémyTomkouani Kodom
}

Published online: 5 February 2019

(C) Springer Nature Switzerland AG 2019

Correction to: Water Air Soil Pollut (2018) 229: 366

https://doi.org/10.1007/s11270-018-

3993-9

In the original publication, the given name of the fourth author was mispelled as Adolp instead of Adolph.

The correct name of the fourth author is Adolph Anga Muleja.

The online version of the original article can be found at https://doi.org/10.1007/s11270-018-3993-9

E. Vunain $(\bowtie) \cdot$ M. Monjerezi

National Resources and Environmental Centre (NAREC), Faculty of Science, Department of Chemistry, University of Malawi,

P.O. Box 280, Chancellor College, Zomba, Malawi

e-mail: evunain@cc.ac.mw

D. Houndedjihou $\cdot$ B. Kodom

Laboratory ofWater Chemistry, Chemistry Department, Faculty of Science, University of Lome, P.O. Box 1515, Lomé-Togo, Bvd

Gnassingbé Eyadema, Lome, Togo
A. A. Muleja
College of Science, Engineering and Technology (CSET),
University of South Africa, Pretoria, South Africa 